\title{
Top management team influence on firms' internationalization complexity
}

Book or Report Section

Accepted Version

Vallone, T., Elia, S., Greve, P., Longoni, L. and Marinelli, D. (2019) Top management team influence on firms' internationalization complexity. In: van Tulder, R., Verbeke, A. and Jankowska, B. (eds.) International Business in a VUCA World: The Changing Role of States and Firms. 1978, 14. Emerald, pp. 203-230. ISBN 9781838672560 doi: https://doi.org/10.1108/S1745-886220190000014012 Available at http://centaur.reading.ac.uk/85153/

It is advisable to refer to the publisher's version if you intend to cite from the work. See Guidance on citing.

Published version at: https://books.emeraldinsight.com/page/detail/International-Business-in-a-VUCA-World/? $\mathrm{k}=9781838672560$

To link to this article DOI: http://dx.doi.org/10.1108/S1745-886220190000014012

Publisher: Emerald

All outputs in CentAUR are protected by Intellectual Property Rights law, including copyright law. Copyright and IPR is retained by the creators or other 
copyright holders. Terms and conditions for use of this material are defined in the End User Agreement.

\section{www.reading.ac.uk/centaur}

\section{CentAUR}

Central Archive at the University of Reading

Reading's research outputs online 


\title{
Top Management Team Influence on Firms' Internationalization Complexity
}

\begin{abstract}
We study the relationship between firms' top management teams (TMT) and internationalization complexity. We consider the effect of three different sets of TMT characteristics - international business orientation intensity, education intensity, and team diversity - on three different and increasingly complex facets of internationalization - international markets intensity, international operations intensity and international country diversity. We argue that more international, highly-educated and diverse TMTs are better able to face the complexity derived from international competition. The results of our empirical analysis show that TMTs having foreign managers or managers with international experience are more likely to be in charge of firms facing higher international operations intensity. Conversely, more educated and more diverse TMTs are associated with complexity deriving from international diversification.
\end{abstract}

Keywords: Microfoundations, internationalization, Top management team, Nationality, International experience, Education, Experience Diversity. 


\section{Introduction}

Historically, research in management and organizational science has been developed at firmlevel of analysis, where the explanations of outcomes (e.g. performance, competitive advantages, strategic decisions etc.) have been found at the same or higher (e.g. industry or country) level of analysis. This approach defines organizations as the main context in which decisions and actions take place and where individual heterogeneity does not have any substantial effect on firm outcomes (Davis-Blake and Pfeffer, 2011). The exclusive attention on macro and meso factors has been widely criticized, as this approach fails to explain the antecedents of firms' routines and capabilities (Kogut and Zander, 1995), while also largely ignoring the notion that "organizations are made up of individuals, and there is no organization without individuals" (Felin and Foss, 2005, p. 1).

The microfoundations approach moves beyond organizational-level constructs and aims to study the underlying building blocks of organizations (Felin, Foss and Ployhart, 2015) by opening the black box of firms' routines and capabilities and by shifting focus to the interactions among individuals. Arguably, Hambrick and Mason (1984) upper echelons framework, which theorizes the relationship between top management team (TMT) characteristics and firms' strategy and performance outcomes, constitutes an intermediate step toward a microfoundational understanding of strategic decision-making in organizations. The core idea is that complex decisions within an organization are largely the outcome of behavioural factors rather than a rational-mechanical quest for economic optimization (Cyert and March, 1963; March and Simon, 1958). Decision-makers' bounded rationality, limited information processing capacity and time constraints prevent managers from formulating optimal rational decisions. Indeed, the higher the complexity and the amount of information to be processed for a specific decision, the higher the likelihood that the decision will be the result of behavioural rather than purely economic factors. Complex decisions are those strategic choices that are likely to have a long-term impact on firm performance and on the capability of the firm to achieve its goals. Thus, strategic decisions are clearly distinct from operational short-term decisions (e.g. inventory decisions) which lend themselves better to calculable solutions (Hambrick and Mason, 1984). Since company strategic choices have an important behavioural component, decision-makers are inevitably influenced by their own values and knowledge, which affect their perception of reality and their evaluation of the relative strengths and weaknesses of alternative solutions.

Firm internationalization decisions arguably provide a suitable context for examining the influence of managers' characteristics and experiences on firms' strategic choices. Indeed, the complexity and multifacetedness of International Business (IB) decisions require the firm's decisionmakers, i.e. the TMT, to gather and process information, while coping with heterogeneous cultural, 
institutional and competitive environments (Carpenter, Sanders and Gregersen, 2001; Greve, Nielsen and Ruigrok, 2009). On the one hand, internationalization offers companies tremendous opportunities, such as increasing firm sales, exploiting ownership and location advantages (Dunning, 1977, 1993), achieving economies of scale (Kogut, 1986), and diversifying market risks (Gomes and Ramaswamy, 1999). On the other hand, it also entails unique challenges and organizational problems (Fatemi, 1984), such as coordinating and managing business activities domestically and internationally, transferring knowledge and organizational practices between firm headquarters and subsidiaries (Kostova, Roth and Dacin, 2008), addressing different cultures and consumers' preferences (Mitchell, Shaver and Yeung, 1992) and dealing with multiple, often conflicting, institutional environments (Kostova and Zaheer, 1999). Hence, to minimize the risks of negative performance or hold-ups of the foreign ventures, it is crucial to understand what types of TMT characteristics are needed to manage the complexity of internationalization.

Our research inquires which TMT characteristics and experiences (i.e. age, nationality, tenure, international experience, functional experience, education level) assist the firm in handling and overcoming the hurdles posed by the organizational and environmental complexity associated with internationalization. More specifically, we consider three distinct facets of internationalization, reflecting three different levels of complexity: international markets intensity (i.e. foreign sales to total sales ratio), international operations intensity (i.e. number of foreign subsidiaries), and international country diversity (i.e. dispersion index of foreign subsidiaries in foreign countries). While international markets intensity entails the least complexity as it can be accomplished also by exporting from the home country, international operations intensity implies a somewhat higher complexity as it accounts for the number of subsidiaries established abroad, and international country diversity is associated with the highest level of complexity as it accounts for the number of different countries in which a firm has invested. We claim that the higher the intensity and diversity of TMT characteristics and experiences, the higher the ability of TMT to manage the complexity of internationalization.

Our empirical analysis, performed on 116 firms across 7 years, i.e. 812 firm-year observations, confirms our expectations. More specifically, results show that TMTs with a high foreign nationality and international working experience intensity are more likely to increase international operation intensity. Furthermore, to foster international country diversity, TMT intensity - in terms of foreign nationality and education - and TMT diversity - especially in terms of functional experience and age - are both required. In other words, more diverse teams can exploit their different backgrounds and manage the complexities derived from internationalization across different countries. 
Our research makes a contribution to both the IB literature, by offering a microfoundations perspective of the strategic internationalization choice, and to the managerial and organizational literature, by offering insights on how firms should organize their TMT to increase the complexity of cross-border investments.

\section{Theoretical background}

The global business environment has considerably changed in the wake of widespread market liberalization as well as economic and industry globalization. Nowadays, the business world is increasingly global (Javidan and House, 2002), encouraging firms to boost their international presence in order to remain successful and competitive. The ongoing globalization process has dramatically changed the business landscape and attracted the attention of a considerable amount of research (Kirca et al., 2012).

The firm internationalization process has been defined in several different ways within the IB literature. Some studies have described internationalization as the "process in which the firm gradually increases their international involvement" (Johanson and Vahlne, 1977, p. 1), whereas others have referred to it as the "extent to which [the firm] undertakes value-adding activities in many different foreign markets" (Hennart, 2007, p. 2). To this multitude of definitions, we note that different studies have used different labels, such as internationalization, degree of internationalization (Sullivan, 1994), global strategic posture (Carpenter and Fredrickson, 2001), geographic diversification, international expansion (Hitt et al., 2006), globalization, and multinationality (Contractor, Kundu and Hsu, 2003; Kirca et al., 2012). In our study, we use the generic term internationalization to refer to the strategy through which a firm expands the sales of its goods or services across borders and undertake value-adding activities in new country markets and geographic regions (Hitt et al., 2006).

Most researchers have accounted for internationalization through a single variable. The most commonly applied measure of firm internationalization is the ratio of foreign sales to total sales (Stopford and Wells, 1972). This is a measure of the firm's commitment to serving customers in foreign markets and highlights the relative importance to the firm of the amount of goods and services sold abroad, irrespective of whether the firm maintains a physical presence outside its home country (Hitt et al., 2011). Other studies have used the ratio of foreign assets to total assets (Kwok and Reeb, 2000), the ratio of foreign employees to total employees, or a count of the number of foreign subsidiaries (Aggarwal et al., 2011).

Even if these measures are widely utilized in international business research, they have been criticized for failing to capture the heterogeneity of international diversification (Vachani, 1991). In 
this regard, other researchers have considered the scope of the firm's foreign expansion, reflecting the geographic dispersion of operations across countries (Barkema and Vermeulen, 1998; Kogut, 1986; Tallman and Li, 1996). To account for cross-country heterogeneity, Hitt et al., (1997) have used an entropy measure to weight the level of diversification across different geographic regions. Entropy measures used in the literature have been based on the number of foreign subsidiaries or on the number of employees in each foreign subsidiary (Hitt et al., 2006).

Increasingly, scholars have adopted multi-dimensional constructs to account for firm internationalization. Sullivan (1994) developed one of the most widely used indices, which is a single composite indicator combining a performance dimension, a structural dimension and an attitudinal dimension of firm internationalization. Another example is the transnationality index introduced by the United Nations Conference of Trade and Development, which has been increasingly used in the literature (Li and Qian, 2005; Lu and Beamish, 2004; Thomas and Eden, 2004). Nevertheless, these multidimensional constructs of firms' internationalization are not exempt from criticism. The most likely risk is to underestimate how distinct internationalization aspects (e.g. intensity, scope, diversity etc.) may be differently affected by the management of the organization and lead to different internationalization performance (Miller, Lavie and Delios, 2016).

In addition, none of these studies have been able to account for one of the most crucial - but also one of the most neglected - aspects of firm internationalization, namely the level of complexity. The first source of international complexity is the internal organization. Indeed, internationalization requires firms to develop complex organizational structures (e.g. divisional or matrix structures), to integrate domestic and foreign business operating models, to introduce sophisticated monitoring and reporting systems to ensure the effective coordination and execution of firm's activities, and to adopt new practices and technologies (George, Wiklund and Zahra, 2005). Another source of internationalization complexity is the external environment (e.g. industry, country, and regional factors) faced by the firm. First, firms operating in multiple countries are confronted with multipoint competition (Roth and O'Donnell, 1996), which forces them to function as integrated wholes. Second, firms' survival in foreign markets depends on their ability to cope with the complexity that derives from heterogeneous cultural, institutional, and competitive environments (Mishina, Pollock and Porac, 2004). Finally, firms must employ a variety of resources to conform their business models to local regulations and to address customers' needs (Asmussen and Goerzen, 2013).

These multifaceted levels of complexity arising from internationalization requires firms to possess high information-processing capacity, high problem-solving capabilities and different forms of knowledge and experience. The extent to which a firm can rely on such capabilities depends on the people who are in charge of the firm's decisions and shape the internationalization process, i.e. 
the TMT. Much of the existing literature has arguably underrated the role of the TMT in the internationalization analysis (Aharoni, Tihanyi and Connelly, 2011; Hennart, 2007; Maitland and Sammartino, 2015). This is at least partially at odds with the intrinsic nature of international business theories which are "theories of managerial choice" (Buckley et al., 2016, p. 316). Hence, in the next paragraph we discuss how different TMT characteristics allow the firm to face the complexity of internationalization.

\section{Hypothesis development}

The international market expansion is a corporate-level strategy for which the top management team is typically responsible (Tan and Mahoney, 2005). Being at the apex of the organization, TMTs play an important role in the firm's internationalization process as they oversee and coordinate company domestic and foreign activities and are in charge of the formulation and implementation of the firm internationalization strategy (Barkema and Shvyrkov, 2007; Hambrick, Cho and Chen, 1996). The top management team can be viewed as the firm information processing centre where critical internal (coming from within the organization) and external (coming from the environment) information are gathered, processed, analysed and, eventually, shared with the rest of the organization (Hinsz, Tindale and Vollrath, 1997). Therefore, additional complexity resulting from the firm internationalization process will weigh on the TMT information processing capacity, potentially jeopardizing the growth of the firm whenever the organization lacks managerial resources and the TMT is faced with information overload (Egelhoff, 1991; Penrose, 1959). Moreover, as suggested by previous research, the information processing demands will remarkably increase when the managers have to deal with multiple and diverse international environments (Tihanyi and Thomas, 2005). Different languages, business environments, national cultures, regulations as well as physical distance do not only affect top managers' risk perceptions, i.e. liability of foreignness (Johanson and Vahlne, 1977), but also substantially increase the information-processing demands which are driven by the differences between the domestic and foreign environments (Birkinshaw, Toulan and Arnold, 2001). Furthermore, managers of smaller MNEs (as in our sample) will generally have even greater difficulties handling the increasing organizational and environmental complexity involved in the firm internationalization process as they do not possess the same resources and managerial expertise of bigger and more established MNEs (Tihanyi and Thomas, 2005).

Therefore, it is critical for international organizations to have top managers with different characteristics, skills and experiences in order to tap into a larger pool of knowledge, capabilities and perspectives that enhance the firm processing capacity and hence, its ability to deal with international 
complexity. Previous studies have shown that individual executives' backgrounds and experiences have a direct impact on the manager's knowledge and skills and on their cognitive capabilities, which are strictly related to their information processing ability (Calori, Johnson and Sarnin, 1994; Hambrick and Mason, 1984; Kor, 2003). Better knowledge about a particular market or industry gained through personal and professional experience in different cultural settings, as well as openmindedness and innovative ways of thinking will help top managers to cope with the complexity and uncertainty of the internationalization process. Hence, we expect that the higher the intensity of such characteristics and experiences in a TMT, the higher the ability to manage the complexity of internationalization. Additionally, the diversity of TMT demographics and experience are also expected to be beneficial to the firm internationalization (Carpenter and Fredrickson, 2001; Rivas, 2012). Indeed, TMT diversity leads to higher creativity, better decision-making quality, and more generally to greater human and social capital (Lee and Park, 2006), which are likely to help managing the complexity arising from the heterogeneity of foreign markets.

Building on these theoretical arguments, we develop several hypotheses in the following section. Drawing from information processing theory, we maintain that top management teams represent an essential asset for their firms, especially when confronted with the ambiguities and uncertainties related to managing and developing foreign operations, and we consider three different sets of TMT characteristics affecting international complexity: TMT international orientation intensity, TMT (international) education intensity, and TMT diversity.

\subsection{TMT international business orientation intensity}

The process of expanding outside of the home boundaries is associated with unique challenges and uncertainties for the management of a firm (Grant, Jammine and Thomas, 1988). This is mostly due to the lack of local market knowledge and hence, the physical and psychological barriers arising from cultural, language, religion and institutional differences between the home and the host country (Johanson and Vahlne, 1977; Kostova and Zaheer, 1999). Therefore, the difficulties of managing operations in non-familiar environments may hamper firms' commitment to enter and invest in new markets, thus reducing its international business orientation. Given that managers' values, attitudes and cognitions, as well as their perceptions, interpretations and decisions, are affected by their nationality and by the type and frequency of their contacts with foreign cultures (Caligiuri, Lazarova and Zehetbauer, 2004; Francesco and Gold, 1998; Hambrick et al., 1998; Hambrick and Mason, 1984; Hofstede, 1980), we claim that TMT ability to deal with the complexity of international business in foreign countries depends on the amount of manager with international working experiences or with foreign nationality. 
The experience of living or working in a different country, with different customs and habits has an important impact on the cognitive orientation of managers (Sambharya, 1996). Researches have outlined several reasons why executives who are dealing with the complexity of firm internationalization would benefit from previous international work (or assignment) experience (Meyer, 2006). A first motivation is that TMTs with substantial international experience are more likely to own a deeper knowledge of the foreign environment, thus reducing the uncertainty of doing business abroad (Lee and Park, 2008). In fact, the experience gained in overseas assignments exposes the managers to international business and foreign practices, which translate into a greater ability to process diverse information more effectively (Greve, Nielsen and Ruigrok, 2009). Another important takeaway from individual international experience is the development of a "global-mindset" (Murtha, Lenway and Bagozzi, 1998) that is defined as the managers' openness and awareness of cultural diversity and their ability to handle it (Gupta and Govindarajan, 2002). A global mindset does not only indicate openness towards change in the organizational status quo, but also willingness to be involved in a global environment (Levy, 2005); it also enhances non-prejudicial and non-judgemental evaluation and interpretation of information (Levy et al., 2007). Finally, international experience enables managers to envision and assess new profitable international investments opportunities and it provides them with the capabilities and networks to sustain the firm international operations (Hamori and Koyuncu, 2011; Tan and Meyer, 2010).

In addition to their international experience, another relevant characteristic of managers is their nationality, which influence their values and cognitions (Greve, Nielsen and Ruigrok, 2009; Nielsen and Nielsen, 2011). The cross-cultural psychology literature has addressed the way nationality impacts the personality of each individual and their underlying orientation and values (Hofstede, 1980; Triandis and Suh, 2002). These nationality-derived qualities affect not only a person's behaviour within the TMT, but also how the person is perceived in a multinational team (Hambrick et al., 1998). Managers' nationalities affect TMT dynamics and their strategic decisionmaking process (Elron, 1997; Kilduff, Angelmar and Mehra, 2000). In fact, foreign-born managers possess valuable knowledge about economic, market, institutional and cultural factors of foreign countries, which may be crucial in international decision-making. Thus, foreign managers have a natural advantage in processing information pertaining to their home countries, as they can filter the abundance of stimuli through selective perceptions and interpretations, and find solutions that improve the information processing capacity (Luo, 2005).

Finally, TMT with international background and orientation, arising either from their foreign nationality or from their international working experience, can rely on an extensive international network that helps them to scan and gather information about foreign countries as well as identify 
potential opportunities in distant and different countries (Carpenter, Sanders and Gregersen, 2000). Interacting and exchanging information with foreign entities, executives gain crucial insights on international markets and are able to reduce the level of uncertainty and complexity associated with international business (Herrmann and Datta, 2005; Tan and Meyer, 2010).

Accordingly, we argue that TMTs with a high proportion of foreign managers or managers with international experience are more likely to pursue international strategies and they will more easily manage the organizational and environmental complexity related to the firm internationalization (Fernández-Ortiz and Lombardo, 2009; Nummela, Saarenketo and Puumalainen, 2004). Indeed, TMT international orientation intensity arising from a high proportion of foreign executives or of executives with international working experience can rely on more extensive global mindset, enhanced information-processing capacity and awareness of international challenges and opportunities. Thus, we formulate the following hypotheses.

- Hypothesis 1(a): the higher the intensity of foreign managers in a TMT, the higher the complexity of the internationalization of a firm;

- Hypothesis 1(b): the higher the intensity of executives with international working experience in a TMT, the higher the complexity of the internationalization of a firm.

\subsection{TMT education intensity}

The literature has identified two important aspects of executives' educational background that may influence the firm's international involvement: the level of education and the international studies (Ganotakis and Love, 2012; Herrmann and Datta, 2005; Piaskowska and Trojanowski, 2014). The former examines managers' knowledge, abilities and socio-cognitive capacities associated with different level of education, while the latter assesses whether managers have gained knowledge and experiences about foreign countries, markets and cultures while studying abroad.

The TMT level of education is a formal measure of the knowledge and skills embedded in the executive team. Education provides managers with more sophisticated problem-solving skills, knowledge and capabilities to deal with complex situations. It has been found that highly-educated managers will contribute to a greater level of innovation and openness to change in the organization (Carpenter and Fredrickson, 2001). Managers will have greater tolerance for ambiguity, higher receptiveness to sudden and unexpected changes and higher propension to deviate from the status quo and implement strategic change (Herrmann and Datta, 2005; Wiersema et al., 1993). Thus, the TMT level of education reflects the quality of the firm managerial resources (Talke, Salomo and Rost, 2010; Wally and Becerra, 2001). Indeed, higher education levels enhance TMT's ability in processing information arising from the internationalization process and, at least partially, prepare the top 
managers to deal with the uncertainties and complexities of the foreign expansion (Ganotakis and Love, 2012; Kirca et al., 2012).

Besides, international studies experience is also an important source of experiential knowledge for the TMT's members (Cui et al., 2015). Overseas education provides managers with several benefits that are not just limited to a better understanding of international business practices. In fact, international experiences gained during their formative years may have a great impact on their identity, values, cognitive abilities and core self-evaluations (Piaskowska and Trojanowski, 2014). Individuals with such experience have developed the abilities to work in cross-cultural settings and minimize the biases and misunderstandings arising from working and dealing with complex and heterogenous cultural environments. Furthermore, international studies provide also network resources that are extended internationally (e.g. alumni networks) and represent unique sources of knowledge (Tan and Meyer, 2010). Thus, such international experience renders TMT members more aware of the opportunities available in the international markets as well as positively affecting their perception of international opportunities (Tihanyi et al., 2000).

Hence, we expect that TMT educational background such as high educational level and high proportion of executives with international study experience will lead to a higher internationalization complexity since executives are more aware and open to new opportunities in overseas markets, have a higher tolerance for uncertainty and develop knowledge and skills that increase their information processing capacity.

- Hypothesis 2(a): the higher the intensity of TMT education, the higher the complexity of the internationalization of a firm;

- Hypothesis 2(b): the higher the intensity of executives with international studies in a TMT, the higher the complexity of internationalization of a firm

\subsection{TMT functional and demographic diversity}

The diversity (or heterogeneity) of TMT characteristics may help the firm in dealing with the complexity entailed by its internationalization process in several different ways. First, TMT diversity increases the information processing capacity by injecting dissimilar perspectives into the team (Amason, Shrader and Tompson, 2006) therefore, increasing the level of open and creative discussion within the team and reducing the "groupthink" phenomenon (Lant and Milliken, 1992). Second, diversity fosters greater human and social capital as diverse teams are more likely to possess different knowledge, skills and capabilities and to rely on the support of a larger social network, which may be essential to sustain the firm internationalization (Kor, 2003; Lovas and Ghoshal, 2000). Third, TMT diversity is crucial as it helps firms to overcome learning myopia (Barkema and Vermeulen, 1998). 
Past researches have also identified two important dimensions of diversity affecting the ability of the firms to manage internationalization, i.e. job-related diversity and demographic diversity (Lee and Park, 2006; Rivas, 2012; Tihanyi et al., 2000). In our research, we investigate the role of functional background diversity as regards the first dimension, and gender and age diversity as regards the second dimension.

Functional background refers to the distinct areas, with the associated goals and problematics, in which a TMT's member has worked along his/her career. Accordingly, an executive's functional background has an important role in shaping his/her cognitive base (Bantel and Jackson, 1989) and it is also a valuable indicator of the type of knowledge that the managers bring on the job (Walsh, 1988). Thus, diverse teams can generate more alternatives to creatively solve complex problems emerging from internationalization (Lee and Park, 2006) and increase the effectiveness and quality of their decision-making as wide ranges of experiences and perspectives boost the TMT capacity to predict, interpret and respond to environmental changes (Carpenter, 2002; Keck, 1997). Concluding, diversity in TMT functional backgrounds for the above-mentioned reasons may be beneficial to face the internationalization complexity.

Another important characteristic that can influence the information-processing capability and decision-making process is gender. While the occurrence of female managers holding positions within the TMT is a relatively recent phenomenon (Krishnan and Park, 2005), there has been a growing interest in uncovering the influence of women in the strategic decision-making process in the last years. Gender diversity provides a more innovative (Tullett, 1995), proactive (Bass and Avolio, 1994), and cautious way of thinking (Huang and Kisgen, 2013) that increases the quality of the decision-making and augment the scanning of the environment (Parola, Ellis and Golden, 2015), which in turn may result into a higher internationalization level.

Finally, the last diversity aspect considered in our research is age. Past studies have found evidence that managerial age influences strategic decision-making perspectives and choices (Herrmann and Datta, 2005, 2006; Tihanyi et al., 2000; Wiersema et al., 1993). Moreover, age is also related to the formulation of innovative and reliable strategies (Barker and Mueller, 2002). On the one hand, older managers are perceived as more effective (i.e. more decisive and reliable), more experienced, but less adaptable (i.e. more inflexible) and more risk-averse than young managers (Taylor and Walker, 1994). On the other hand, younger managers are believed to be more energetic, dynamic, flexible in modifying their decisions and possess greater physical and mental stamina that help them to process information better and quicker (Child, 1974), although they are perceived as less reliable due to their lack of expertise. Nevertheless, the limited experience and gullibility of young managers will be offset by the experience, wisdom and cautious of older TMT's members (Rivas, 
2012). Likewise, the greater information-processing capacity, creativity and stamina of younger managers will counterbalance the risk-aversion, rigidity and inertia of older managers. Hence, we maintain that TMTs with higher age diversity among its members provide the right balance between experience, innovation and risk-propension that may be beneficial to face the complexity of internationalization.

Taken together, TMTs with greater diversity in terms of functional background, age and gender will reach high level of internationalization complexity.

- Hypothesis 3(a): the higher the functional background diversity of a TMT, the higher the complexity of the internationalization of a firm;

- Hypothesis 3(b): the higher the gender diversity of a TMT, the higher the complexity of the internationalization of a firm;

- Hypothesis 3(c): the higher the age diversity of a TMT, the higher the complexity of the internationalization of a firm.

\section{Methods}

\subsection{Data and sample}

In order to test our hypotheses, we selected a sample of 116 manufacturing firms and collected data and information on the firm financials, their TMTs, subsidiaries, and countries of operations over a seven-years period, from 2010 to 2016. This sample is the result of a search undertaken through Orbis database (dataset provided by Bureau Van Dijk) considering the following criteria: firms have to be UK-based, publicly listed companies ${ }^{1}$, global ultimate owners (GUOs), with a number of employees included between 50 to $1,000^{2}$ and operating in a manufacturing sector ${ }^{3}$. The underlying reasons behind these criteria are several. The restriction to UK-based firms answers to the need to cope with the variance surrounding TMT conceptualization across different corporate governance contexts (Kaczmarek and Ruigrok, 2013). Listed companies must disclose certified business and financial information on a regular basis, which ensures the quality and reliability of our data. GUOs are the decision-makers in their group, thus their TMTs formulate and implement strategic decisions in complete autonomy. The number of employees is imposed between 50 to 1,000 employees for the following reasons; very small firms may not have the capabilities and resources to internationalize (especially to adopt equity entry modes), while very large multinational companies are characterized

\footnotetext{
${ }^{1}$ The 116 companies composing our sample were always publicly listed in the period considered (2010 to 2016)

${ }^{2}$ For at least one of the years in the period considered (2010 to 2016)

${ }^{3}$ First two digits of the primary industry code considering NACE Rev. 2 classification will have to be between 10 to 32 included
} 
by limited managerial discretion (relatively small influence of the TMT) and organizational inertia. Finally, we chose to focus on manufacturing companies as they tend to internationalize by gradually increasing their international commitment (Johanson and Vahlne, 1977).

Information related to countries of operations and number of subsidiaries were hand collected from company public financial reports, while financial data were exported from Orbis and Fame databases; both datasets are provided by Bureau Van Dijk. Finally, having defined the TMT as the executive directors of the Board of Directors (Nielsen and Nielsen, 2013; Nielsen, 2009; Piaskowska and Trojanowski, 2014), we hand collected information regarding the TMT of each firm for each year. Starting from the company annual reports and other financial statements, we collected the names and surnames of the TMT members; afterwards, consulting different sources such as firm's financial reports, company websites, corporate press releases, Companies House website, Bloomberg, Reuters, and LinkedIn, consistently with the strategic leadership literature, we collected demographic information, career length, company tenure, and data regarding working and education experience (Finkelstein, Hambrick and Cannella, 2009; Finkelstein and Hambrick, 1996). Demographic information was also collected for the other members of the Board of Directors, i.e. the non-executive directors.

At the end of the data collection phase, we obtained data about 116 firms over 7 years, for a total number of 812 TMTs. However, because of missing data and the two-years lag between the dependent and independent variables adopted in our econometrics models, the final sample used for our analyses counts 107 firms and 498 observations.

\subsection{Dependent variables}

The aim of our research is to study the relationship between the TMT characteristics and the complexity of internationalization. In order to capture this latter concept, we considered three distinct dimensions of the firm internationalization reflecting three different and increasing levels of complexity: international markets intensity, international operations intensity and international country diversity.

International markets intensity, measured as the ratio between foreign sales and total sales, represents the importance of selling goods or services outside of the home market, irrespective of whether the firm maintains a physical presence abroad (Hitt et al., 2011; Stopford \& Wells, 1972). Considering both exports and sales through sales subsidiaries, this construct allows to measure the complexity of serving different markets and customers who may have specific preferences and expectations in terms of products and services offered. This measure of internationalization reflects the lower level of complexity, since it captures also those companies that serve the foreign markets only through export, i.e. without opening any subsidiary in foreign countries. 
International operations intensity is measured as the number of foreign ventures established abroad. It is a count of the number of subsidiaries operating outside of UK (Aggarwal et al., 2011). This measure reflects a higher level of complexity with respect to the previous one, as it captures the difficulty of managing and coordinating a certain number of foreign subsidiaries (sales, manufacturing, distribution subsidiaries etc.) in one or more foreign countries.

Lastly, International operations diversity refers to the dispersion of a firm's international operations across multiple host countries (Allen and Pantzalis, 1996; Goerzen and Beamish, 2003; Miller, Lavie and Delios, 2016). This is a measure of the depth and breadth of internationalization which simultaneously considers the number of countries in which the firm operates (breadth) and the relative importance of each country within the firm operations (depth). This variable is constructed through Blau's (1977) index, thus

$$
\text { International diversity }=1-\sum_{i=1}^{n} p_{i}^{2}
$$

where $p$ is the percentage of subsidiaries the firm owns in the country $i$, and $n$ is the number of countries in which the firm operates. The higher the dispersion of subsidiaries around the world, the closer this variable will be to 1 ; conversely, the lower the dispersion of subsidiaries, the closer this variable will be to 0 . This variable reflects the highest degree of complexity, since it captures the difficulties of managing and coordinating multiple subsidiaries across a variety of countries, meaning that firms have to deal with heterogeneous cultures, languages, legislations, markets, customers, competitors and political systems

\subsection{Explanatory variables}

In line with our hypotheses, we developed three sets of explanatory variables that measure eight observable characteristics of the TMT members ${ }^{4}$.

The first set of explanatory variables represents the TMT international business orientation intensity and is measured through two distinct variables: the nationality intensity and the international working experience intensity. Nationality intensity is a variable that measures the proportion of foreign executives in the board, thus it is the ratio of the number of non-British board members to the board size. Similarly, International working experience intensity is a variable that measures the proportion of TMT members who had over their careers at least one working experience outside UK

\footnotetext{
${ }^{4}$ We refer to TMT as the executive members of the board of directors of the firm. Therefore, most of the explanatory and control variables at the team-level were measured only on the executive directors. However, the variables regarding the demographics information of the managers were calculated considering also the non-executive members of the BoD. The reason behind this decision lies in the fact that these characteristics (i.e. nationality, gender, and age) have low job-relatedness but high visibility; this means they can shape the attitudes and behaviours of the board members, even when the directors do not work strictly together on a daily basis (Pelled, 1996). Nationality, gender, and age influence the TMT decisions even when a strong work interaction is not required, as it happens among executives and non-executives.
} 
(i.e. international working experience). The working experience of a non-British executive in UK is not considered as international working experience (foreigners do add value as non-British sitting in the Board, but this is already captured by the nationality intensity).

The second set of explanatory variables is the TMT educational intensity and is measured through two distinct variables: the education level intensity and the international education intensity. Education level intensity is a variable that assesses the average level of education of the TMT members. For each TMT member we collected information regarding his/her educational background and, particularly, his/ her highest degree. Then, we assigned a score ${ }^{5}$ from 1 to 7 to each executive based on his/her highest degree and finally we computed the average of these scores at the team-level. The other educational explanatory variable is the International education intensity, which measures the proportion of TMT members who have studied abroad (at least once). Here, the definition of "International" differs from the international working experience. "International" does not mean "outside of the UK" but it means "outside of the country of origin". This means that a non-British executive who studied in his/her home country does not have any international education experience, while a non-British executive who studied outside his/her home country (also in UK) does have international education experience. This is because studying abroad, exchanging views, meeting and living with people from different cultures provide individuals with an open mindset and knowledge about the risks and challenges of a cross-cultural setting.

The third set of explanatory variables refers to the TMT diversity (i.e. heterogeneity) and is measured through three different variables: functional diversity, gender diversity, and age diversity. Functional diversity is a variable that captures the breadth of skill-sets and network resources available to the TMT (Ancona and Caldwell, 1992). To measure this variable, we initially defined ten functional areas $^{6}$ and classified each working experience of each executive into one of these areas. Then, for each executive, we calculated his/her dominant function (i.e. the function in which the executive worked for the most of his/her life). Finally, we calculated the TMT functional diversity through the Blau's (1977) index:

$$
\text { Functional diversity }=1-\sum_{i=1}^{n} p_{i}^{2}
$$

\footnotetext{
${ }^{5}$ Educational qualifications are ranked as following: high school diploma or its equivalent (1), vocational qualification (2), executive programme (3), bachelor level (4), graduate master level (5), postgraduate master level (6) and finally, doctor level (7).

${ }^{6}$ The identified functional areas were based on Cannella et al. (2008), with slight adaptations to account for contextual differences, and comprise the following categories: production/operation divisions (PROD), research, technology, clinical (RESE), marketing, sales, commercial, corporate roles (MASA), manufacturing, design and engineering (ENMA), finance and accounting (FACC), personnel/HR (PERS), law (LEGA), strategy and corporate development (STRA) and others (OTHE). The data was collected based on a detailed data collection manual developed from a comprehensive review of the functional experience literature.
} 
where $p_{i}$ is the percentage of executives with $i$ as dominant function and $n$ is the TMT size. The higher the number of different dominant functions in a TMT, the higher the functional diversity. Gender diversity measures the heterogeneity of the board in terms of gender. Like functional diversity, it is measured through Blau's (1977) index, but in this case $p_{i}$ represents the proportion of board members of gender $i$. Age diversity measures the heterogeneity of the board in terms of age. Contrarily to the functional and gender diversity, age diversity is not computed through the Blau's (1977) index since this index can be only used to measure the dispersion of categorical variables. Therefore, as suggested by previous studies (Bunderson and Van der Vegt, 2018; Rivas, 2012), we have used the coefficient of variation to compute age diversity, that is the ratio of the standard deviation to the mean. This measure allows to weigh the standard deviation (the dispersion) by the magnitude of the variable (the mean).

\subsection{Control variables}

Several control variables were included in the analysis to account for other firm- and team-level factors that may explain variances in the capability of the firm to manage the complexity derived from internationalization. Specifically, we have included the following control variables in our three models: Return on Assets (ROA), operating revenue, R\&D intensity, gearing ratio, company age, TMT size, average TMT tenure, CEO experience, CEO founder, board independence, industry dummies and time dummies.

$R O A$ is a financial indicator that measures how profitable a firm is relative to its total assets. In fact, it is computed as the ratio between net income and total assets (equal to equity plus debt). Firms with higher and better financial performance might have more opportunities of diversifying their business abroad. On the other hand, some poorly performing firms may want to internationalize to improve their financial performances.

Operating revenue consists of the total operating sales of the firm in a given year. It is used here as a measure of the firm size. Firm size can strongly affects the degree of internationalization of the firm itself; larger firm should have more resources and capabilities to deal with the complexity of internationalization (Henderson and Fredrickson, 1996) and they have greater chances to achieve economies of scales (Tuppura et al., 2008).

Gearing ratio is a financial indicator that measures the leverage of the firm. It is calculated as the ratio between total debt and total equity; a higher debt-to-equity ratio means that firm assets are mainly funded through debt capital rather than equity capital. We use the debt-to-equity ratio as a proxy of the capability of the firm to finance its growth; a higher ratio means that the firm will incur in higher risks to fund its international ventures as debt will be the main source of financing. 
Research \& Development $(R \& D)$ intensity is the ratio between $\mathrm{R} \& \mathrm{D}$ expenses and operating revenue. Several studies have found that $R \& D$ investments may translate into better products and services offered and therefore, greater chances to export/ sell those products to/ in foreign countries (Herrmann \& Datta, 2005).

Company age is the current age of the firm, which is computed as difference between the year of our sample and the company foundation year. Previous studies agree upon the inverse relationship between company age and internationalization (Reuber and Fischer, 1997). Older firms may lack the flexibility and understanding of an always-changing environment and therefore, they may struggle to adapt and overcome the complexities of internationalization.

TMT size measures the number of executives' directors of the Board of Directors. TMT size is controlled as it is a valuable proxy of the team information processing-capacity; bigger teams may be capable of processing varied and greater amount of information, which is particularly important when expanding firms operations to new markets or countries (Carpenter and Sanders, 2004).

Average TMT tenure is the mean number of years that TMT members have spent working as an executive in the firm of our sample. Longer tenured executives tend to develop homogenized views and restricted perception of the reality; they also tend to be more risk adverse and base their decisions on past experiences rather than more scientific and rational reasons (Finkelstein \& Hambrick, 1996). However, executives with longer tenures will have a greater knowledge of the company resources and capabilities. Moreover, longer serving TMTs tend to strengthen group socialization, which reduces the conflict among the member facilitating the successful implementation of international strategies (Amason and Sapienza, 1997).

CEO experience measures the number of years the current $\mathrm{CEO}$ of the company worked as CEO during his/her career. A CEO who has worked in this position for several years is more familiar with the decision-making process and can use his/her expertise to handle more complex situations and face the strategic challenges of global organizations (Miller, Lavie and Delios, 2016). On the contrary, CEO with limited experience are less likely to undertake strategies which are resource-intensive and extremely uncertain, i.e. internationalization (Hamori and Koyuncu, 2015).

We also control for CEO founder status, which is a dummy variable whose value is equal to 1 when the CEO is also the founder (or co-founder) of the firm, 0 otherwise. Family businesses (FBs) tend to be less internationalized than non-FBs (Segaro, Larimo and Jones, 2014). In fact, CEO founders may be less risk-averse than CEO agents and push the internationalization process of the firm (Chittoor, Aulakh and Ray, 2017), but in the long term, they may lack the external networks and the management capabilities to sustain it (Souder, Simsek and Johnson, 2012). 
Board independence is the ratio of the number of non-executive directors to the board size. Higher board independence (i.e. higher proportion of non-executives) should reinforce the board effectiveness and strength in its supervisory and monitoring role; previous studies show a positive effect on the firm internationalization (Chen, 2011).

Finally, we control for industry sectors and temporal effects through industry and time dummies. Industry dummies are 4 dummy variables that indicate the level of technology of the sector in which the firm operates. Although all the companies in our sample are manufacturing firms, some firms may work in more technology-intensive sectors than others, with different requirements and competition in terms of internationalization. According to the Eurostat classification ${ }^{7}$, there are four technology clusters and for each of them we have a created a dummy variable (High Technology, Medium/High Technology, Medium/Low Technology, and Low Technology). Time dummies are used to control for possible exogenous factors influencing the internationalization of the firms of our sample in the period considered. Therefore, we have created a time dummy for each year of our sample (we lose two years dummies because of the time lag between the dependent and independent variables).

\subsection{Empirical model}

Our final database is a panel dataset, where each observation reflects the internationalization (measured through our three dependent variables) of each company over a specific period of time (i.e. 2010-2016). We included a time lag of 2 years between the dependent and independent variables (Wally \& Becerra, 2001), meaning that the dependent variables are calculated at time $\mathrm{T}$ and regressed on explanatory and control variables calculated at time $\mathrm{T}-2^{8}$. The panel data nature and the two years lag of the explanatory and control variables of our dataset helps to better identify a causal relation between TMT observable characteristics and the firm degree of internationalization, by reducing also potential endogeneity and reverse causality problems.

As regards the methodology, we employed three alternative models, one for each dependent variable. Since the proxies accounting for international markets intensity and international country diversity are continuous and range from 0 to 1 , a fractional logit model has been employed to estimate the coefficients of these two dependent variables. Conversely, a negative binomial regression has been selected for international operations intensity, given the negative binomial distribution of this

\footnotetext{
${ }^{7}$ Classification is based on NACE Rev.2 2-digit Sic Codes. In particular, 21 and 26 are classified as High-Technology; 20, 27, 28, 29, 30 Medium-High-Technology; 19, 22, 23, 24, 25, 33 Medium-Low-Technology; 10, 11, 12, 13, 14, 15, $16,17,18,31,32$ Low-Technology

${ }^{8}$ We also employed a 1-year lag for the explanatory and control variables, but results were not significant. This might be due to the medium-run decision process underlying cross-border investments, which on average require more than one year from the initial planning to the final implementation.
} 
dependent variable. We expect the explanatory variables accounting for TMT intensity and diversity to be increasingly significant when shifting from the dependent variable accounting for a lower level of complexity (i.e. international markets intensity) to the dependent variable accounting for the higher level of complexity (i.e. international operations diversity).

\section{Results}

Table 1 shows the correlations among our dependent, explanatory, and control variables together with some descriptive statistics. The table shows that the levels of correlation among the variables are generally very low. The only variables with a considerable level of correlation (>0.6) are TMT size with the board independence, as larger TMTs generally have a greater proportion of executives than smaller TMTs and accordingly, a smaller number of non-executive directors. We further tested for multicollinearity and inspected the values of variance inflation factors (VIFs). The VIF values range from 1.22 to 3.32 , hence they are well below the suggested maximum threshold of 10 (Guo, Chumlea and Cockram, 1996).

Table 2 shows in detail the coefficients, significances, and standard errors of our estimations. Models 1, 2 and 3 employs international markets intensity, international operations intensity and international country diversity as dependent variable, respectively, thus reflecting an increasing level of internationalization complexity. The results of our analyses clearly show different levels of significance of the explanatory variables in relation to the different facets of internationalization complexity that we considered in each single model.

Model 1 shows no significant relation between the TMT observable characteristics and international markets intensity. Hence, none of our hypotheses is confirmed when considering the dependent variable reflecting the lower level of complexity.

Conversely, model 2, reflecting an average level of complexity, confirms both hypotheses 1a and 1b. Indeed, Nationality intensity $(p<0.10)$ and International working experience intensity $(p<$ $0.05)$ exhibit a positive and significant relation with International operations intensity. Nevertheless, hypotheses 2 and 3 are not supported by the analyses.

Finally, model 3, whose dependent variable is associated to the highest level of complexity, shows that most of our hypotheses are confirmed. Nationality intensity has a positive correlation with International country diversity $(p<0.05)$, while no significant correlation was found between International working experience and this facet internationalization complexity. Hence, only hypothesis 1a turns out to be confirmed. Concerning hypotheses 2, Education level intensity does show a positive correlation with internationalization diversity $(p<0.05)$, thus confirming hypothesis 2a, while International education intensity is not significant. Finally, as regards hypotheses 3, both 
Functional diversity $(p<0.01)$ and Age diversity $(p<0.10)$ show a positive correlation with International operations diversity, while Gender diversity does not. Hence, hypotheses 3a and 3c are confirmed.

For what concerns the control variables of our models, only few of them have a significant impact on the dependent variables. Operating revenue is significantly and positively correlated with the complexity of internationalization in model 3. The greater availability of resources allows the firm to increase the diversification of its international activities. The $R \& D$ intensity has a significant and negative correlation with the complexity of internationalization in model 1, which might reflect the fact that intensive research activities distract the firm from maximizing its internationalization activities. Finally, average TMT tenure shows a positive correlation with the complexity of internationalization in model 3. This confirms the importance of the TMT experience as decisionmaker of the firm. Longer tenure provides TMTs with the required organizational knowledge experience and confidence to pursue more aggressive internationalization strategies (Chen, 2011).

\section{Discussions and conclusions}

We investigate the influence of TMT characteristics on firms' internationalization strategy. Firms dealing with internationalization face high uncertainty and volatility because of different laws, consumer preferences, cultures, and competitors: for this reason, internationalization is one of the most complex environment for managerial decision-making (Prahalad, 1990). We look at TMTs as a bundle of managerial resources, which can provide the firm with key sources of knowledge and expertise. These resources allow firms to improve the information gathering and processing and overcome the complexity associated with internationalization. Consequently, we hypothesized that more international, educated and diverse TMTs are better able to manage the complexity that arise from internationalization.

We have developed three distinct measures, which represent three different aspects of the firm's internationalization and three different (and growing) levels of complexity. We start from the International markets intensity, which shows firm's commitment to foreign markets: this is the lowest level of complexity since it does not consider the difficulties of managing foreign subsidiaries, but only the management of sales abroad (also through direct or indirect export). International operations intensity represents a medium level of complexity that comes from the need to manage a number of subsidiaries in foreign countries. Lastly, International country diversity measures the highest level of complexity in our analyses: managing a high number of foreign subsidiaries becomes more and more difficult when these subsidiaries are dispersed across several countries. The empirical analysis shows 
that, as internationalization complexity increases, more international, educated and diverse TMTs are required. In particular, while international market intensity does not seem to be affected by TMT characteristics, international operation intensity requires TMT with high foreign nationality and international working experience intensity. Conversely, international country diversity requires both TMT intensity - in terms of foreign nationality and education - and TMT diversity - in terms of functional experience and age. Below, we provide more insights about our results.

The hypotheses related to the intensity of TMT international business orientation refer to the familiarity of TMT members with the international environment; this familiarity derives from the inborn cultures of foreign executives or from the experiential knowledge and networks developed during a working experience abroad. Given the top managers' key position as ultimate responsible for the firm strategic choices, both their origins and their experience significantly influence firms' decision-making process by fostering the development of an internationalization strategy (Nielsen, 2010). The results partially support our expectations; our models have demonstrated that, on the one hand, the abundance of foreign people within the TMT (nationality intensity) enhances the internationalization complexity in terms of both operation intensity and country diversity. On the other hand, the proportion of executives with international working experience (international working experience intensity) is critical only to foster international operations intensity but not international country diversity. We argue that this is mainly because an inborn knowledge about foreign cultures and values has more impact on an individual's cognitive orientation than a working experience abroad. Specifically, while international assignments result in benefits for the decisionmaking process such as international markets knowledge, skills, and informal network contacts, these experiences are limited in time and scope (Caligiuri \& DeSanto, 2001). The values embedded in national culture, instead, have a deeper and more enduring effect on executives' orientation since they influence the fundamental cognitions of the decision-maker; executives use these cognitions to scan, identify, interpret, and utilize the information needed for strategic decisions (Shaw, 1990). In particular, TMTs benefit from the presence of foreigners because of their deep knowledge about international markets, especially that one of their home countries. This knowledge increases the awareness of the different and distant markets' functioning and the understanding of the tastes of customers that could be culturally very distant (Nielsen \& Nielsen, 2009). Moreover, culturally diverse groups over time outperform homogenous groups in range of perspectives and alternatives generated during the decision-making process (Watson et al., 1993). This aspect empowers the TMT with a higher ability to cope with the managerial complexity arising from the management of different number of subsidiaries and thus it impacts the international operations intensity. In addition, variation in cultural values among top managers will lead to preferences for different 
strategic actions (Hambrick \& Brandon, 1988), extending the firm's presence with different subsidiaries in different countries and increasing the international country diversity.

Our second set of hypotheses concerns the TMT's educational background, with a focus on education level intensity and international education intensity. Previous literature has recognized the key role of education in affecting cognitive ability, capacity for information processing, tolerance for ambiguity, and propensity or receptivity to innovation (Bantel and Jackson, 1989; Hambrick and Mason, 1984). The results partially support our hypotheses. The education level intensity has a significant impact on the highest level of international complexity, i.e. international country diversity, while international education intensity does not have any significant effect. As regards this latter result, we claim that the possible open-minded attitude towards other cultures gained during the studies abroad is often too short to impact the managers' cognitive orientation. Conversely, TMTs with a high education level intensity ensure long lasting knowledge and skills to the firm, contributing to greater levels of innovation and openness to change (Carpenter \& Frederickson, 2001). Hence, highly educated executives not only ensure higher abilities and competencies in the management of complex business environment, but also the capacity of promptly grasp the right opportunities offered by foreign markets. Moreover, high education endows managers with higher awareness of the different tastes and habits among customers coming from culturally and physically distant countries, as well as the ability to understand different business practises, thus fostering international country diversity.

Our third set of hypotheses refer to the TMT diversity according to different dimensions: functional background (functional background diversity), gender (gender diversity) and age (age diversity). We argue that heterogeneity among TMT members enriches the decision-making and information processing with different competences, innovativeness and the correct balance between flexibility and wisdom. Our results show that higher levels of heterogeneity in functional and age diversity correspond to higher internationalization country diversity and, hence, higher internationalization complexity. As regards functional background diversity, the executives' career backgrounds influence the way problems are perceived, how information is processed and the kinds of strategic actions that are taken (Lee \& Park, 2006). TMTs composed of managers with different dominant functions are characterised by competences in different fields such as marketing, production, finance etc. These highly differentiated competences within a TMT can lead the firm to identify, assess and exploit the specific opportunities from each country. In this way, TMTs can successfully manage a greater number of subsidiaries and also locate them in different countries (international country diversity). As regards age diversity, a variety of ages guarantees the right balance between the innovativeness and flexibility of young managers and wisdom and experience 
of older managers. This perfect equilibrium ensures a good ability in the management of complex situations (Rivas, 2012) like a great number of subsidiaries across several countries.

We believe that our results contribute to both international business and strategy and organizational literatures. As regards the former, we provide a microfoundation perspective of the internationalization decision, by showing the key role of TMT characteristics and experience in fostering this strategic choice. We also provide a contribution by focusing our attention on the complexity of internationalization, an issue that is seldom taken into account in international business literature despite its crucial importance for the success of the foreign venture. We capture this concept by considering three different measures of internationalization, each capturing an increasing level of internationalization complexity. We also contribute to the strategy and organizational literature by showing how TMT that have a higher proportion of foreign managers, with higher education levels and with diverse people in terms of age and functional experience, are better equipped to face the complexity arising from international investments across different countries. TMTs with members having intensive international working experience are also well prepared to manage the complexity arising from a high number of investments abroad, although they seem to lose their effectiveness when these investments are dispersed across countries.

In spite of the promising and satisfying results of our research, some limitations come to light. First, relying on a sample of UK based companies only, reduces the generalization of our results, enlarging the scope of the analysis to other home countries may help in this sense. Second, it would be interesting to enlarge the study to larger firms in order to increase the variety of the observed firms' internationalization complexity. Another important limitation of our study is to use observable characteristics as a proxy of managers' cognitions rather than psychological traits. Although this approach is largely adopted in the Upper Echelons studies, more accurate researches should rest on multidisciplinary approach which comprise also psychology. Finally, considering longer periods of time might help to understand how the internationalization of the firm has changed with the composition of the firm. Moreover, it might help to tease out the possible reverse causality between firm internationalization and TMT composition. Despite these limitations, we believe our research contributes not only to the literature, but also to a better understanding of what type of competences, abilities, orientations and knowledge impacts specific aspects of the internationalization process, thus offering some insights to the human resources management and to those stakeholders who are planning the internationalization of their companies. In particular, TMTs of international-oriented firms should be diversified, highly educated and multi-cultural in order to be able to face the complexity of internationalization. 


\section{TABLES}

Table 1 - Correlation matrix and descriptive statistics of variables employed in models

\begin{tabular}{|c|c|c|c|c|c|c|c|c|c|c|c|c|c|c|c|c|c|c|c|c|c|}
\hline & Variables & 1 & 2 & 3 & 4 & 5 & 6 & 7 & 8 & 9 & 10 & 11 & 12 & 13 & 14 & 15 & 16 & 17 & 18 & 19 & 20 \\
\hline 1 & Int. markets orient. & $\overline{1}$ & & & & & & & & & & & & & & & & & & & \\
\hline 2 & Int. operations orient. & 0.392 & 1 & & & & & & & & & & & & & & & & & & \\
\hline 3 & Int. diversity & 0.437 & 0.694 & 1 & & & & & & & & & & & & & & & & & \\
\hline 4 & Nationality Intensity & 0.326 & 0.457 & 0.323 & 1 & & & & & & & & & & & & & & & & \\
\hline 5 & Int. Work. Exp. Int. & 0.374 & 0.331 & 0.269 & 0.552 & 1 & & & & & & & & & & & & & & & \\
\hline 6 & Functional diversity & -0.024 & 0.018 & 0.036 & -0.128 & -0.116 & 1 & & & & & & & & & & & & & & \\
\hline 7 & Gender diversity & 0.115 & 0.025 & 0.095 & 0.015 & 0.064 & 0.023 & 1 & & & & & & & & & & & & & \\
\hline 8 & Age Diversity & 0.096 & 0.064 & 0.081 & 0.043 & 0.120 & 0.043 & -0.090 & 1 & & & & & & & & & & & & \\
\hline 9 & Avg Education Level & 0.156 & 0.028 & -0.002 & 0.052 & 0.150 & -0.027 & -0.147 & -0.022 & 1 & & & & & & & & & & & \\
\hline 10 & Int. Education Int. & 0.164 & 0.113 & 0.141 & 0.397 & 0.328 & 0.020 & -0.123 & 0.077 & 0.288 & 1 & & & & & & & & & & \\
\hline 11 & $R O A$ & 0.003 & 0.040 & 0.027 & -0.056 & -0.111 & 0.123 & 0.131 & -0.004 & -0.212 & -0.145 & 1 & & & & & & & & & \\
\hline 12 & Operating revenue & -0.113 & 0.167 & 0.123 & 0.119 & 0.124 & -0.002 & 0.071 & -0.086 & -0.091 & 0.125 & 0.140 & 1 & & & & & & & & \\
\hline 14 & Gearing ratio & -0.121 & 0.005 & -0.009 & 0.062 & -0.012 & -0.106 & -0.108 & 0.032 & -0.082 & 0.092 & 0.032 & 0.357 & -0.066 & 1 & & & & & & \\
\hline 15 & Company age & -0.161 & -0.006 & -0.017 & -0.226 & -0.188 & 0.029 & 0.118 & 0.054 & -0.320 & -0.186 & 0.230 & 0.115 & -0.087 & 0.085 & 1 & & & & & \\
\hline 16 & TMT size & -0.109 & -0.031 & 0.046 & -0.170 & -0.201 & 0.570 & 0.032 & 0.191 & -0.202 & -0.033 & 0.150 & -0.034 & -0.014 & -0.037 & 0.173 & 1 & & & & \\
\hline 17 & Avg TMT tenure & -0.047 & 0.047 & 0.090 & -0.112 & -0.204 & 0.051 & 0.102 & -0.123 & -0.336 & -0.111 & 0.246 & 0.022 & -0.059 & 0.003 & 0.295 & 0.185 & 1 & & & \\
\hline 18 & CEO Experience & -0.083 & 0.064 & -0.038 & 0.001 & -0.047 & 0.136 & 0.047 & 0.036 & -0.216 & -0.077 & 0.145 & -0.034 & -0.046 & -0.014 & 0.216 & 0.273 & 0.559 & 1 & & \\
\hline 19 & CEO Founder & -0.031 & 0.030 & 0.013 & 0.009 & -0.100 & 0.096 & -0.133 & 0.081 & -0.094 & -0.067 & 0.105 & -0.052 & -0.045 & 0.032 & -0.158 & 0.312 & 0.124 & 0.258 & 1 & \\
\hline \multirow[t]{6}{*}{20} & Board independence & 0.189 & 0.118 & 0.086 & 0.237 & 0.233 & -0.417 & 0.065 & -0.093 & 0.223 & 0.111 & -0.144 & 0.115 & 0.068 & 0.015 & -0.193 & -0.743 & -0.229 & -0.249 & -0.191 & 1 \\
\hline & Observations (No.) & 478 & 498 & 498 & 498 & 498 & 498 & 498 & 498 & 498 & 498 & 498 & 498 & 498 & 498 & 498 & 498 & 498 & 498 & 498 & 498 \\
\hline & Mean & 0.498 & 4.271 & 0.504 & 0.104 & 0.287 & 0.513 & 0.081 & 0.141 & 4.221 & 0.067 & -0.013 & 60966 & 6.998 & 0.468 & 39.17 & 2.843 & 8.153 & 10.249 & 0.124 & 0.509 \\
\hline & Std. Dev. & 0.347 & 4.867 & 0.303 & 0.194 & 0.328 & 0.181 & 0.148 & 0.048 & 1.059 & 0.164 & 0.192 & 110664 & 52.80 & 0.922 & 36.93 & 1.091 & 4.746 & 7.782 & 0.330 & 0.144 \\
\hline & Min & 0 & 0 & 0 & 0 & 0 & 0 & 0 & 0.023 & 1 & 0 & -1.539 & 6 & 0 & 0 & 3 & 1 & 1 & 1 & 0 & 0.167 \\
\hline & $\operatorname{Max}$ & 1 & 36 & 0.927 & 1 & 1 & 0.833 & 0.480 & 0.349 & 7 & 1 & 0.351 & 1549051 & 674.8 & 9.591 & 126 & 7 & 31 & 53 & 1 & 0.800 \\
\hline
\end{tabular}


Table 2 - Results of regression analyses related to model 1, 2, and 3

\begin{tabular}{|c|c|c|c|c|c|c|}
\hline \multirow{2}{*}{ Variables } & \multicolumn{2}{|c|}{$\begin{array}{c}\text { Model 1 } \\
\text { Int. Markets. Orient. }\end{array}$} & \multicolumn{2}{|c|}{$\begin{array}{c}\text { Model } 2 \\
\text { Int. Op. Orient. } \\
\end{array}$} & \multicolumn{2}{|c|}{$\begin{array}{c}\text { Model 3 } \\
\text { Int. Diversity } \\
\end{array}$} \\
\hline & Coefficient & $\begin{array}{c}\text { Standard } \\
\text { Error }\end{array}$ & Coefficient & $\begin{array}{c}\text { Standard } \\
\text { Error }\end{array}$ & Coefficient & $\begin{array}{c}\text { Standard } \\
\text { Error }\end{array}$ \\
\hline Nationality Intensity & 1.188 & 0.746 & $0.647 *$ & 0.346 & $0.593 * *$ & 0.276 \\
\hline Int. Work Exp. Int. & 0.398 & 0.294 & $0.517 * *$ & 0.213 & 0.120 & 0.156 \\
\hline Functional diversity & -0.389 & 0.599 & 0.133 & 0.389 & $0.515 * * *$ & 0.192 \\
\hline Gender diversity & 0.269 & 0.501 & 0.127 & 0.419 & 0.608 & 0.398 \\
\hline Age Diversity & -2.785 & 2.615 & 1.285 & 1.129 & $1.509^{*}$ & 0.890 \\
\hline Avg Education Level & 0.038 & 0.073 & 0.038 & 0.071 & $0.100 * *$ & 0.044 \\
\hline Int. Education Int. & -0.590 & 0.760 & -0.194 & 0.388 & -0.055 & 0.212 \\
\hline$R O A$ & -0.175 & 0.295 & 0.190 & 0.286 & -0.133 & 0.169 \\
\hline Operating revenue & 0.000 & 0.000 & 0.000 & 0.000 & $0.000 * *$ & 0.000 \\
\hline$R \& D$ Intensity & $-0.002 * * *$ & 0.001 & 0.000 & 0.001 & 0.000 & 0.000 \\
\hline Gearing ratio & -0.089 & 0.056 & -0.032 & 0.039 & 0.016 & 0.019 \\
\hline Company age & -0.004 & 0.004 & -0.001 & 0.004 & -0.003 & 0.004 \\
\hline TMT size & -0.064 & 0.107 & 0.026 & 0.075 & 0.021 & 0.045 \\
\hline Avg TMT tenure & -0.001 & 0.018 & 0.017 & 0.012 & $0.025 * * *$ & 0.008 \\
\hline CEO Experience & 0.007 & 0.012 & 0.003 & 0.008 & -0.001 & 0.004 \\
\hline CEO Founder & -0.266 & 0.331 & 0.013 & 0.297 & 0.025 & 0.126 \\
\hline Board independence & -0.004 & 0.638 & -0.071 & 0.479 & 0.375 & 0.277 \\
\hline Year 2012 & $0.000 * * *$ & 0.000 & $0.000 * * *$ & 0.000 & $0.000 * * *$ & 0.000 \\
\hline Year 2013 & 0.033 & 0.079 & 0.064 & 0.076 & $0.084 * *$ & 0.039 \\
\hline Year 2014 & -0.010 & 0.072 & $0.147^{*}$ & 0.076 & $0.168 * * *$ & 0.052 \\
\hline Year 2015 & -0.055 & 0.099 & $0.264 * * *$ & 0.076 & $0.192 * * *$ & 0.061 \\
\hline Year 2016 & -0.015 & 0.103 & $0.309 * * *$ & 0.075 & $0.195 * * *$ & 0.063 \\
\hline Industry technology level 1 & $0.000 * * *$ & 0.000 & $0.000 * * *$ & 0.000 & $0.000 * * *$ & 0.000 \\
\hline Industry technology level 2 & 0.483 & 0.425 & -0.203 & 0.373 & -0.023 & 0.369 \\
\hline Industry technology level 3 & 0.186 & 0.397 & 0.159 & 0.331 & 0.094 & 0.331 \\
\hline Industry technology level 4 & 0.531 & 0.393 & 0.110 & 0.336 & -0.181 & 0.328 \\
\hline Constant & 0.216 & 0.917 & 17.487 & 219.166 & $-1.429 * * *$ & 0.497 \\
\hline Observations (No.) & \multicolumn{2}{|c|}{478} & \multicolumn{2}{|c|}{498} & \multicolumn{2}{|c|}{498} \\
\hline Wald Chi2 & \multicolumn{2}{|c|}{73.55} & \multicolumn{2}{|c|}{64.69} & \multicolumn{2}{|c|}{101.04} \\
\hline P-value & \multicolumn{2}{|c|}{0.000} & \multicolumn{2}{|c|}{0.000} & \multicolumn{2}{|c|}{0.000} \\
\hline
\end{tabular}

$* * * \mathrm{p}<0.01 ; * * \mathrm{p}<0.05 ;{ }^{*} \mathrm{p}<0.1$ 


\section{Reference}

Aggarwal, R., Berrill, J., Hutson, E. and Kearney, C. (2011) 'What is a multinational corporation? Classifying the degree of firm-level multinationality', International Business Review, 20(5) Elsevier Ltd, pp. 557-577.

Aharoni, Y., Tihanyi, L. and Connelly, B.L. (2011) 'Managerial decision-making in international business: A forty-five-year retrospective', Journal of World Business

Allen, L. and Pantzalis, C. (1996) 'Valuation of the Operating Flexibility of Multinational Corporations', Journal of International Business Studies, 27(4) Palgrave Macmillan UK, pp. 633653.

Amason, A.C. and Sapienza, H.J. (1997) 'The Effects of Top Management Team Size and interaction Norms on Cognitive and Affective Conflict', Journal of Management, 23(4), pp. 495516.

Amason, A.C., Shrader, R.C. and Tompson, G.H. (2006) 'Newness and novelty: Relating top management team composition to new venture performance', Journal of Business Venturing, 21(1) Elsevier, pp. 125-148.

Ancona, D.G. and Caldwell, D.F. (1992) 'Demography and design: Predictors of new product team development', Organization Science

Asmussen, C.G. and Goerzen, A. (2013) 'Unpacking Dimensions of Foreignness: FirmSpecific Capabilities and International Dispersion in Regional, Cultural, and Institutional Space', Global Strategy Journal, 3(2) John Wiley \& Sons, Ltd, pp. 127-149.

Bantel, K.A. and Jackson, S.E. (1989) 'Top Management and Innovation in Banking: Does the Composition of the Top Management Make a Difference', Strategic Management Journal, 10(Special Issue), pp. 107-124.

Barkema, H.G. and Shvyrkov, O. (2007) 'Does Top Management Team Diversity promote or hamper foreign expansion?', Strategic Management Journal, 28(2), pp. 663-680.

Barkema, H.G. and Vermeulen, F. (1998) 'International Expansion through Start up or Acquisition: A Learning Perspective', The Academy of Management Journal, 41(1), pp. 7-26.

Barker, V.L. and Mueller, G.C. (2002) 'CEO characteristics and firm R\&D spending', Management Science, , pp. 782-801.

Bass, bernard M. and Avolio, B.J. (1994) Improving organizational effectiveness through transformational leadership. Sage.

Birkinshaw, J., Toulan, O. and Arnold, D. (2001) 'Global account management in multinational corporations: Theory and evidence', Journal of International Business Studies, 32(2), p. 231.

Blau, P.M. (1977) 'INEQUALITY AND HETEROGENEITY - A PRIMITIVE THEORY OF SOCIAL STRUCTURE', Free Press, New York.

Buckley, P.J., Chen, L., Clegg, L.J. and Voss, H. (2016) 'Experience and FDI Risk-taking: A Microfoundational Reconceptualization', Journal of International Management, 22(2) Elsevier 
Inc., pp. 131-146.

Bunderson, J.S. and Van der Vegt, G.S. (2018) 'Diversity and Inequality in Management Teams: A Review and Integration of Research on Vertical and Horizontal Member Differences', Annual Review of Organizational Psychology and Organizational Behaviour

Caligiuri, P., Lazarova, M. and Zehetbauer, S. (2004) 'Top managers' national diversity and boundary spanning: Attitudinal indicators of a firm's internationalization', Journal of Management Development, 23(9), pp. 848-859.

Calori, R., Johnson, G. and Sarnin, P. (1994) 'CEOs' cognitive maps and the scope of the organization', Strategic Management Journal, 15(6), pp. 437-457.

Carpenter, M.A. (2002) 'The implications of strategy and social context for the relationship between top management team heterogeneity and firm performance', Strategic Management Journal, 23(3), pp. 275-284.

Carpenter, M.A. and Fredrickson, J.W. (2001) 'Top Management Teams , Global Strategic Posture, and the Moderating Role of Uncertainty', Academy of Management Journal, 44(3), pp. $533-545$.

Carpenter, M.A., Sanders, G. and Gregersen, H.B. (2001) 'Bundling Human Capital with Organizational Context: The Impact of International Assignment Experience on Multinational Firm Performance and CEO Pay', Academy of Management Journal, 44(3), pp. 493-511.

Carpenter, M.A. and Sanders, W.G. (2004) 'The effects of top management team pay and firm internationalization on MNC performance', Journal of Management, 30(4), pp. 509-528.

Carpenter, M.A., Sanders, W.G. and Gregersen, H.B. (2000) 'International assignment experience at the top can make a bottom line difference', Human Resource Management, 39(3), pp. 277-285.

Child, J. (1974) 'MANAGERIAL AND ORGANIZATIONAL FACTORS ASSOCIATED WITH COMPANY PERFORMANCE PART I', Journal of Management Studies, 11(3) Blackwell Publishing Ltd, pp. 175-189.

Chittoor, R., Aulakh, P.S. and Ray, S. (2017) 'Microfoundations of Firm Internationalization: The Owner Ceo Effect', Global Strategy Journal

Contractor, F.J., Kundu, S.K. and Hsu, C.-C. (2003) 'A three-stage theory of international expansion: the link between multinationality and performance in the service sector', Journal of International Business Studies, 34(1) Palgrave Macmillan UK, pp. 5-18.

Cui, L., Li, Y., Meyer, K.E. and Li, Z. (2015) 'Leadership Experience Meets Ownership Structure: Returnee Managers and Internationalization of Emerging Economy Firms', Management International Review, 55(3), pp. 355-387.

Cyert, R.M. and March, J.G. (1963) A behavioral theory of the firm. Englewood Cliffs N.J.: Prentice-Hall.

Davis-Blake, A. and Pfeffer, J. (2011) 'Just a Mirage: The Search for Dispositional Effects in Organizational Research.', Academy of Management Review, 14(3) Academy of Management Briarcliff Manor, NY 10510, pp. 385-400. 
Dunning, J. (1977) 'Trade, Location of Economic Activity and the MNE: A Search for an Eclectic Approach', in The International Allocation of Economic Activity. London: Palgrave Macmillan, pp. 395-418.

Dunning, J.H. (1993) Multinational enterprises and the global economy. Wokingham: Addison-Wesley Publishing Company.

Egelhoff, W.G. (1991) 'Information-Processing Theory and the Multinational Enterprise', Journal of International Business Studies, 22(3) Palgrave Macmillan UK, pp. 341-368.

Elron, E. (1997) 'Top management teams within multinational corporations: Effects of cultural heterogeneity', Leadership Quarterly, 8(4), pp. 393-412.

Fatemi, A.M. (1984) 'Shareholder Benefits from Corporate International Diversification', The Journal of Finance, 39(5) Blackwell Publishing Ltd, pp. 1325-1344.

Felin, T. and Foss, N.J. (2005) 'Strategic organization: A field in search of microfoundations', Strategic Organization, 3(4), pp. 441-455.

Felin, T., Foss, N.J. and Ployhart, R.E. (2015) 'The Microfoundations Movement in Strategy and Organization Theory', The Academy of Management Annals, 9(1), pp. 575-632.

Fernández-Ortiz, R. and Lombardo, G.F. (2009) 'Influence of the capacities of top management on the internationalization of SMEs', Entrepreneurship and Regional Development, 21(2), pp. 131-154.

Finkelstein, S. and Hambrick, D.C. (1996) Strategic Leadership: Top Executives and Their Effects on Organizations.

Finkelstein, S., Hambrick, D.C. and Cannella, A.A. (2009) Strategic leadership : theory and research on executives, top management teams, and boards. Oxford University Press.

Francesco, A.M. and Gold, B.A. (1998) International Organizational Behavior: Text, Readings, Cases, and Skills. Pearson.

Ganotakis, P. and Love, J.H. (2012) 'Export propensity, export intensity and firm performance: The role of the entrepreneurial founding team', Journal of International Business Studies, 43(8), pp. 693-718.

George, G., Wiklund, J. and Zahra, S.A. (2005) 'Ownership and the Internationalization of Small Firms', Journal of Management

Goerzen, A. and Beamish, P.W. (2003) 'Geographic scope and multinational enterprise performance', Strategic Management Journal, 24(13) John Wiley \& Sons, Ltd, pp. 1289-1306. Available at: 10.1002/smj.357 (Accessed: 27 March 2019).

Gomes, L. and Ramaswamy, K. (1999) 'An Empirical Examination of the Form of the Relationship Between Multinationality and Performance', Journal of International Business Studies, 30(1) Palgrave Macmillan UK, pp. 173-187.

Grant, R.M., Jammine, A.P. and Thomas, H. (1988) 'Diversity, Diversification, and Profitability Among British Manufacturing Companies, 1972-1984', Academy of Management Journal, 31(4) Academy of Management Briarcliff Manor, NY 10510 , pp. 771-801. 
Greve, P., Nielsen, S. and Ruigrok, W. (2009) 'Transcending borders with international top management teams: A study of European financial multinational corporations', European Management Journal, 27(3) Pergamon, pp. 213-224. A

Guo, S.S., Chumlea, W.C. and Cockram, D.B. (1996) 'Use of statistical methods to estimate body composition', The American Journal of Clinical Nutrition, 64(3) Narnia, pp. 428S-435S.

Gupta, A.K. and Govindarajan, V. (2002) 'Cultivating a global mindset', Academy of Management Perspectives, 16(1) Academy of Management Briarcliff Manor, NY 10510 , pp. 116126.

Hambrick, D.C., Cho, T.S. and Chen, M. (1996) 'The Influence of Top Management Team Heterogeneity on Firms ' Competitive Moves', Administrative Science Quarterly, 41(4), pp. 659684 .

Hambrick, D.C., Davison, S.C., Snell, S.A. and Snow, C.C. (1998) 'When groups consists of multiple nationalities: Towards a new understanding of the implications', Organization Studies, 19, pp. 181-205.

Hambrick, D.C. and Mason, P.A. (1984) 'Upper Echelons: The Organization as a Reflection of Its Top Managers.', Academy of Management Review, 9(2), pp. 193-206.

Hamori, M. and Koyuncu, B. (2011) 'Career advancement in large organizations in Europe and the United States do international assignments add value', The International Journal of Human Resource Management, 22(4)

Hamori, M. and Koyuncu, B. (2015) 'Experience Matters? The Impact of Prior CEO Experience on Firm Performance', Human Resource Management, 54(2), pp. 23-44.

Henderson, A.D. and Fredrickson, J.W. (1996) 'Information-processing demands as a determinant of CEO compensation', Academy of Management Journal, 39(3), pp. 575-606.

Hennart, J.F. (2007) 'The theoretical rationale for a multinationality-performance relationship', Management International Review, 47(3), pp. 423-452.

Herrmann, P. and Datta, D.K. (2005) 'Relationships between Top Management Team Characteristics and International Diversification: an Empirical Investigation', British Journal of Management, 16, pp. 69-78.

Herrmann, P. and Datta, D.K. (2006) 'CEO experiences: Effects on the choice of FDI entry mode', Journal of Management Studies, (May 2016)

Hinsz, V.B., Tindale, R.S. and Vollrath, D.A. (1997) 'The emerging conceptualization of groups as information processors.', Psychological Bulletin, 121(1), pp. 43-64.

Hitt, M.A., Dacin, M.T., Tyler, B.B. and Park, D. (1997) 'UNDERSTANDING THE DIFFERENCES IN KOREAN AND U.S. EXECUTIVES' STRATEGIC ORIENTATIONS', Strategic Management Journal, 18(2) Wiley-Blackwell, pp. 159-167.

Hitt, M.A., Tihanyi, L., Miller, T. and Connelly, B. (2006) 'International Diversification: Antecedents, Outcomes, and Moderators', Journal of Management, 32(6), pp. 831-867.

Hofstede, G. (1980) Culture's consequences: International differences in work-related 
values. Beverly Hills, CA: Sage.

Huang, J. and Kisgen, D.J. (2013) 'Gender and corporate finance: Are male executives overconfident relative to female executives?', Journal of Financial Economics, 108(3) NorthHolland, pp. 822-839.

Javidan, M. and House, R.J. (2002) 'Leadership and cultures around the world: findings from GLOBE', Journal of World Business, 37(1), pp. 1-2.

Johanson, J. and Vahlne, J.-E. (1977) 'The Internationalization Process of the Firm: A Model of Knowledge Development and Increasing Foreign Market Commitments', Journal of International Business Studies, 8(1), pp. 23-32.

Kaczmarek, S. and Ruigrok, W. (2013) 'In at the Deep End of Firm Internationalization: Nationality Diversity on Top Management Teams Matters', Management International Review, 53(4), pp. 513-534.

Keck, S.L. (1997) 'Top Management Team Structure: Differential Effects by Environmental Context', Organization Science, 8(2) INFORMS , pp. 143-156.

Kilduff, M., Angelmar, R. and Mehra, A. (2000) 'Top Management-Team Diversity and Firm Performance : Examining the Role of Cognitions', Organization Science, 11(1), pp. 21-34.

Kirca, A.H., Deligonul, S., Perryy, M.Z. and Cavusgil, S.T. (2012) 'A Multilevel Examination of the Drivers of Firm Multinationality: A Meta-Analysis', Journal of Management, (May 2010)

Kogut, B. (1986) 'Designing global strategies: profiting from operation flexibility', Thunderbird International Business Review, 28(1) John Wiley \& Sons, Ltd, pp. 15-17.

Kogut, B. and Zander, U. (1995) 'Knowledge, Market Failure and the Multinational Enterprise: A Reply', Journal of International Business Studies, 26(2) Palgrave Macmillan UK, pp. 417-426.

Kor, Y.Y. (2003) 'Experience-Based Top Management Team Competence and Sustained growth', Organization Science, 14(6), pp. 707-719.

Kostova, T., Roth, K. and Dacin, M.T. (2008) 'Institutional Theory in the Study of Multinational Corporations: A Critique and New Directions', The Academy of Management Review, 33(4), pp. 994-1006.

Kostova, T. and Zaheer, S. (1999) 'Organizational Legitimacy under Conditions of Complexity: The Case of the Multinational Enterprise', The Academy of Management Review, 24(1), pp. 64-81.

Krishnan, H.A. and Park, D. (2005) 'A few good women-on top management teams', Journal of Business Research, 58(12) Elsevier, pp. 1712-1720.

Kwok, C.C.Y. and Reeb, D.M. (2000) 'Internationalization and Firm Risk: An UpstreamDownstream Hypothesis', Journal of International Business Studies, 31(4) Palgrave Macmillan UK, pp. 611-629.

Lant, T.K. and Milliken, F.J. (1992) 'The role of managerial learning and interpretation in 
strategic persistence and reorientation: an empirical exploration', 13

Lee, H. and Park, J. (2008) 'The Influence of Top Management Team International Exposure on International Alliance Formation', Journal of Management Studies, 45(5)

Lee, H.U. and Park, J.H. (2006) Top team diversity, internationalization and the mediating effect of international alliances British Journal of Management.

Levy, O. (2005) 'The influence of top management team attention patterns on global strategic posture of firms', Journal of Organizational Behavior, 26, pp. 797-819.

Levy, O., Beechler, S., Taylor, S. and Boyacigiller, N.A. (2007) 'What we talk about when we talk about "global mindset": Managerial cognition in multinational corporations', Journal of International Business Studies, 38(2), pp. 231-258.

Li, L. and Qian, G. (2005) 'Dimensions of International Diversification', Journal of Global Marketing, 18(3-4) Taylor \& Francis Group, pp. 7-35.

Lovas, B. and Ghoshal, S. (2000) 'Strategy as guided evolution', Strategic Management Journal, 21(9) Wiley-Blackwell, pp. 875-896.

Lu, J.W. and Beamish, P.W. (2004) 'International Diversification and Firm Performance: The S-Curve Hypothesis', The Academy of Management Journal, 47(4), pp. 598-609.

Luo, Y. (2005) 'How does globalization affect corporate governance and accountability? A perspective from MNEs', Journal of International Management, 11(1) Elsevier, pp. 19-41.

Maitland, E. and Sammartino, A. (2015) 'Managerial cognition and internationalization', Journal of International Business

March, J.G. and Simon, H.A. (1958) Organizations. Oxforf, England: Wiley.

Meyer, K.E. (2006) 'Globalfocusing: From Domestic Conglomerates to Global Specialists*', Journal of Management Studies, 43(5) John Wiley \& Sons, Ltd (10.1111), pp. 11091144.

Miller, S.R., Lavie, D. and Delios, A. (2016) 'International intensity, diversity, and distance: Unpacking the internationalization-performance relationship', International Business Review, 25(4) Elsevier Ltd, pp. 907-920.

Mishina, Y., Pollock, T.G. and Porac, J.F. (2004) 'Are more resources always better for growth? Resource stickiness in market and product expansion', Strategic Management Journal, 25(12) John Wiley \& Sons, Ltd, pp. 1179-1197. A

Mitchell, W., Shaver, J.M. and Yeung, B. (1992) 'Getting there in a global industry: Impacts on performance of changing international presence', Strategic Management Journal, 13(6) John Wiley \& Sons, Ltd, pp. 419-432.

Murtha, T.P., Lenway, S.A.N.N. and Bagozzi, R.P. (1998) 'Global Mind-Sets and Cognitive Shift in a Complex Multinational Corporation', Strategic Management Journal, 19(2), pp. 97-114.

Nielsen, B.B. and Nielsen, S. (2011) 'The role of top management team international orientation in international strategic decision-making: The choice of foreign entry mode', Journal 
of World Business, 46(2) Elsevier Inc., pp. 185-193.

Nielsen, B.B. and Nielsen, S. (2013) Top management team nationality diversity and firm performance: A multilevel study Strategic Management Journal.

Nielsen, S. (2009) 'Why do top management teams look the way they do? A multilevel exploration of the antecedents of TMT heterogeneity', Strategic Organization, 7(3) SAGE PublicationsSage UK: London, England, pp. 277-305.

Nielsen, S. (2010) 'Top Management Team Internationalization and Firm Performance: The Mediating Role of Foreign Market Entry', Management International Review

Nummela, N., Saarenketo, S. and Puumalainen, K. (2004) 'A Global Mindset -A Prerequisite for Successful Internationalization?’, Canadian Journal of Administrative Sciences

Parola, H.R., Ellis, K.M. and Golden, P. (2015) 'Performance effects of top management team gender diversity during the merger and acquisition process', Management Decision, 53(1) Emerald Group Publishing Limited, pp. 57-74.

Pelled, L.H. (1996) 'Demographic Diversity, Conflict, and Work Group Outcomes: An Intervening Process Theory', Organization Science, 7(6) INFORMS , pp. 615-631. Ltd.

Penrose, E.T. (1959) The theory of the growth of the firm. Oxford: Blackwell Publishing

Piaskowska, D. and Trojanowski, G. (2014) 'Twice as smart? The importance of managers' Formative-Years' international experience for their international orientation and foreign acquisition decisions', British Journal of Management, 25, pp. 40-57.

Prahalad, C.K. (1990) 'The Core Competence of the Corporation', Harvard Business Review

Reuber, R.A. and Fischer, E. (1997) 'The Influence of the Management Team 's International Experience on the Internationalization Behaviors of SMEs', Journal of International Business Studies, 28(4), pp. 807-825.

Rivas, J.L. (2012) 'Diversity \& internationalization: The case of boards and TMT's', International Business Review, 21(1) Elsevier Ltd, pp. 1-12.

Roth, K. and O’Donnell, S. (1996) 'Foreign Subsidiary Compensation Strategy: An Agency Theory Perspective', Academy of Management Journal, 39(3) Academy of Management Briarcliff Manor, NY 10510, pp. 678-703.

Sambharya, R.B. (1996) 'Foreign Experience of Top Management Teams and International Diversification Strategies of U . S . Multinational Corporations', Strategic Management Journal, 17(9), pp. 739-746.

Segaro, E.L., Larimo, J. and Jones, M. V. (2014) 'Internationalisation of family small and medium sized enterprises: The role of stewardship orientation, family commitment culture and top management team', International Business Review, 23(2), pp. 381-395.

Souder, D., Simsek, Z. and Johnson, S.G. (2012) 'The differing effects of agent and founder CEOs on the firm's market expansion', Strategic Management Journal 
Stopford, J.M. and Wells, J.L.T. (1972) Managing the Multinational Enterprise: Organization of the Firm and Ownership of the Subsidiary.French Edi. Basic Books.

Sullivan, D. (1994) 'Measuring the Degree of Internationalization of a Firm', Journal of International Business Studies, 25(2) Palgrave Macmillan UK, pp. 325-342.

Talke, K., Salomo, S. and Rost, K. (2010) 'How top management team diversity affects innovativeness and performance via the strategic choice to focus on innovation fields', Research Policy, 39(7) North-Holland, pp. 907-918.

Tallman, S. and Li, J. (1996) 'Effects of International Diversity and Product Diversity on the Performance of Multinational Firms', Academy of Management Journal, 39(1) Academy of Management Briarcliff Manor, NY 10510, pp. 179-196.

Tan, D. and Mahoney, J.T. (2005) 'Examining the Penrose effect in an international business context: the dynamics of Japanese firm growth in US industries', Managerial and Decision Economics, 26(2) John Wiley \& Sons, Ltd., pp. 113-127.

Tan, D.C. and Meyer, K.E. (2010) 'Business groups' outward FDI: A managerial resources perspective', Journal of International Management, 16, pp. 154-164.

Taylor, P.E. and Walker, A. (1994) 'The Ageing Workforce: Employers' Attitudes towards Older People', Work, Employment and Society, 8(4) Sage PublicationsSage CA: Thousand Oaks, CA, pp. 569-591.

Thomas, D.E. and Eden, L. (2004) 'What is the Shape of the Multinationality-Performance Relationship?', Multinational Business Review, 12(1) Emerald Group Publishing Limited, pp. 89110 .

Tihanyi, L., Ellstrand, A.E., Daily, C.M. and Dalton, D.R. (2000) 'Composition of the Top Management Team and Firm International Diversification', Journal of Management, 26(6)

Tihanyi, L. and Thomas, W.B. (2005) 'Information-processing demands and the multinational enterprise: a comparison of foreign and domestic earnings estimates', Journal of Business Research, 58(3) Elsevier, pp. 285-292.

Triandis, H.C. and Suh, E.M. (2002) 'Cultural Influences on Personality', Annual Review of Psychology, 53(1) Annual Reviews 4139 El Camino Way, P.O. Box 10139, Palo Alto, CA 943030139, USA, pp. 133-160.

Tullett, A.D. (1995) 'The adaptive-innovative (A-I) cognitive styles of male and female project managers: Some implications for the management of change', Journal of Occupational and Organizational Psychology, 68(4) John Wiley \& Sons, Ltd (10.1111), pp. 359-365.

Tuppura, A., Saarenketo, S., Puumalainen, K., Jantunen, A. and Kyläheiko, K. (2008) 'Linking knowledge, entry timing and internationalization strategy', International Business Review, 17(4) Pergamon, pp. 473-487.

Vachani, S. (1991) 'Distinguishing Between Related and Unrelated International Geographic Diversification: A Comprehensive Measure of Global Diversification', Journal of International Business Studies, 22(2) Palgrave Macmillan UK, pp. 307-322.

Wally, S. and Becerra, M. (2001) 'Top Management Team Characteristics and Strategic 
Changes in International Diversification: The case of US Multinationals the European Community', Group \& Organization Management, 26(2), pp. 165-188.

Walsh, J.P. (1988) 'Selectivity and Selective Perception: An Investigation of Managers' Belief Structures and Information Processing', Academy of Management Journal, 31(4) Academy of Management Briarcliff Manor, NY 10510 , pp. 873-896.

Wiersema, M.F., Bantel, K.A., Strategic, S., Journal, M., Oct, N. and Wiersema, M.F. (1993) 'Top Management Team Turnover as an Adaptation Mechanism : The Role of the Environment', Strategic Management Journal, 14(7), pp. 485-504. 